\title{
Pengaruh Stres Kerja, Dan Beban kerja Terhadap Kinerja Karyawan
}

\author{
Sulastri ${ }^{1}$ \\ ${ }^{1}$ Program Studi Manajemen Universitas Muhammadiyah Bengkulu \\ trisulas2605@gmail.com
}

\begin{abstract}
The title of this research is the Effect of Job Stress, and Workload, on Employee Performance at the Honda Astra Motor Dealer in Bengkulu City. This research is based on the importance of the company to minimize work stress and workload faced by employees, so that later employee performance will improve. This study aims to determine the effect of work stress and workload on employee performance.

The population of this study is all employees of the Honda Astra Motor Dealer Bengkulu City, amounting to 30 people. The sampling technique used is Cencus sampling.
\end{abstract}

Keywords: Job Stress, Workload, and Employee Performance.

\section{BAB I}

\section{PENDAHULUAN}

\subsection{Latar Belakang Masalah}

Manusia perlu memenuhi kebutuhan untuk keberlangsungan hidupnya di dunia. Bekerja menjadi hal yang wajib dilakukan, sebab dengan bekerja manusia akan dapat memenuhi segala kebutuhannya. Rizki yang di turunkan oleh Allah harus dicari secara aktif oleh manusia dengan cara bekerja. Apabila bekerja itu adalah fitrah manusia maka jelaslah bahwa manusia yang enggan bekerja sesungguhnya dia itu melawan fitrahnya sendiri, menurunkan derajat identitas dirinya sebagai manusia, untuk kemudian runtuh dalam kedudukan yang lebih hina dari binatang.

Secara alami manusia akan terdorong untuk mencurahkan tenaga agar menghasilkan harta yang bisa digunakan untuk kebutuhan hidup. Kebutuhan - kebutuhan manusia itu sangat beragam dan tidak mungkin terpenuhi dengan mengisolasi diri dari sesamanya, karena itu dalam kehidupan seseorang dalam masyarakat ( society ) akan 
terjadi saling menukar hasil tenaganya dengan tenaga orang lain. Atas dasar inilah maka individu yang hidup dalam masyarakat akan mencurahkan tenaganya dalam rangka menghasilkan harta untuk bisa langsung dihabiskan dan ditukar, bukan sekedar menghabiskan tenaganya secara langsung sebab kebutuhannya banyak dan dia membutuhkan harta yang tidak dia miliki serta membutuhkan pemenuhan dari tenaga orang lain secara langsung, misalnya pendidikan dan kesehatan.

Pada saat zaman sekarang ini, antar perusahaan atau organisasi bisnis saling bersaing untuk menguasai pangsa pasar. Beradaptasi dan berinovasi dilakukan agar perusahaan dapat tetap bertahan di lingkungan bisnis. Apabila perubahan kondisi lingkungan perusahaan yang fluktuatif tidak dapat diantisipasi oleh perusahaan maka dapat berpengaruh terhadap keberadaan perusahaan tersebut. Oleh karena itu, perusahaan harus mampu menghadapi, mengatasi, dan mengantisipasi perubahan kondisi lingkungan bisnis dan memberikan respon yang tanggap, cepat, tepat, dan efektif serta efisien. Perkembangan usaha dan organisasi perusahaan sangatlah tergantung pada produktivitas tenaga kerja yang ada di perusahaan (Mangkunegara, 2000:1). Maka perusahaan harus memiliki sumber daya manusia yang berkualitas agar dapat bersaing dan memberikan tanggapan terhadap perubahan lingkungan perusahaan.

Keberhasilan suatu organisasi juga tergantung pada kemampuannya untuk mengelola berbagai macam sumber daya yang dimilikinya, salah satu yang sangat penting yaitu Sumber Daya manusia (SDM). SDM senantiasa melekat pada setiap sumber daya organisasi apapun sebagai faktor penentu keberadaan dan perannya dalam memberi kontribusi ke arah pencapaian tujuan organisasi secara efektif dan efisien. Sumber Daya Manusia (SDM) merupakan aset berharga bagi perusahaan atau organisasi bisnis karena merupakan poros utama dalam melakukan tindakan, menetukan tujuan, serta pengambilan keputusan yang tepat untuk mencapai tujuan yang diharapkan. Untuk mendapatkan SDM yang handal dan berkualitas dibutuhkan pengelolaan yang tepat. 
Adanya pengelolaan yang tepat mulai dari proses perekrutan, penyeleksian, pengklarifikasian, dan penempatan karyawan sesuai dengan kemampuan dapat meningkatkan kinerja perusahaan. Pengelolaan sumber daya manusia secara professional dapat memberikan keseimbangan antara kemampuan dan tuntutan perusahaan terhadap tuntutan karyawan. Kunci utama agar perusahaan dapat berkembang secara baik yaitu keseimbangan antara karyawan dan perusahaan (Mangkunegara, 2000:1).

Semakin berkembangnya perusahaan, maka perubahan kondisi lingkungan perusahaan yang terjadi didalam organisasi maupun diluar organisasi baik berdampak secara langsung ataupun tidak langsung dapat berdampak terhadap produktifitas karyawan dan perusahaan akan meningkatkkan target produktifitas dan semakin kompleks. Tingginya tuntutan kinerja atau standar target kinerja yang ditentukan oleh perusahaan, maka karyawan akan berusaha untuk mencapai target kinerja yang telah ditetapkan oleh perusahaan. Namun jika kualitas berkembangnya perusahaan, SDM yang dimiliki tidak dapat beradaptasi dengan perubahan lingkungan yang terjadi, maka akan menimbulkan tingkat stres dalam bekerja dan tekanan beban kerja terhadap karyawan yang berdampak pada kinerja karyawan.

Pesatnya perkembangan ilmu pengetahuan dan teknologi dewasa ini menimbulkan perkembangan dan pertumbuhan di segala aspek kehidupan yang berkaitan adanya permasalahan baru yang sangat kompleks. Perkembangan tersebut tidak terlepas pada organisasi baik pemerintah maupun swasta. Hal ini terlihat dengan timbulnya prosedur prosedur kerja baru peralatan kerja yang lebih modern, persyaratan kerja baru yang mengharuskan organisasi untuk selalu tanggap dan waspada yang juga memungkinkan untuk menyesuaikan diri.

Pada hakikatnya setiap perkembangan itu mengacu pada usaha untuk meningkatkan kehidupan organisasi atau perusahaan menjadi lebih baik di antaranya dengan meningkatkan kualitas kerja seperti keterampilan yang dimiliki. Jika memperhatikan 
berbagai faktor yang mempengaruhi perkembangan organisasi atau perusahaan maka faktor sumber daya manusia tetap merupakan faktor yang paling penting. Dalam hal ini tenaga kerja yang ada merupakan salah satu faktor yang sangat mempengaruhi, karena bila tenaga kerja yang digunakan dalam kemampuan terbatas maka produktivitas juga akan terbatas seiring dengan kemampuan dan kualitasnya.

Sumber daya manusia merupakan faktor utama dalam mencapai tujuan perusahaan. Pencapaian tujuan perusahaan tidak terlepass dari manusia yang berperan aktif dan dominan setiap kegiatan kebutuhan karyawan dengan tuntutan dan kemampuan perusahaan. Manajeman sumber daya manusia juga dapat didefinisikan pula sebagai suatu pengelolaan dan pendayagunaan sumber daya yang ada pada individu (karyawan). Organisasi membutuhkan sumber daya manusia atau karyawan dalam pencapaian tujuan secara efektif dan efisien. Tersedianya sumber daya yang profesional telah menjadi kebutuhan strategis perusahaan atau organisasi.

Kebutuhan ini didasari oleh pemahaman bahwa manusia adalah penentu atas semua kinerja organisasi. Meujudkan sumber daya manusia yang profesional bagi sebuah perusahaan kadang - kadang mengalami hambatan. Hambatan tersebut bisa muncul dari faktor organisasi maupun dari dalam diri karyawan sendiri.

Honda (Astra Motor) adalah salah satu perusahaan Astra Internasional yang bergerak dibidang operations dengan produk sepeda motor Honda. Yang dulunya merupakan main distributor sepeda motor Honda. Saat ini Astra Motor merupakan main dealer yang mencangkup sebelas wilayah (region) di seluruh Indonesia. Salah satunya berada diwilayah Bengkulu.

Pada saat observasi awal yang dilakukan pada Dealer Honda Astra Motor Kota Bengkulu, peneliti mewawancarai Ifan Ardiansyah selaku kepala cabang (Branch Head) dan karyawan lainya di Dealer Honda Astra Motor Kota Bengkulu, tentang jumlah penjualan unit sepeda motor pada penjualan tiga bulan terakhir (Juli, Agustus, dan 
September). Wawancara dilakukan pada hari senin,tanggal 21 Oktober jam dua siang di

Dealer Honda Astra Motor Kota Bengkulu. Adapun hasil wawancaranya yaitu:

Tabel 1.1

Penjualan Sepeda Motor Tiga Bulan Terakhir (Juli, Agustus,dan September)

\begin{tabular}{|l|c|}
\hline \multicolumn{1}{|c|}{ Bulan } & Unit Terjual \\
\hline Juli & 127 Unit \\
\hline Agustus & 132 Unit \\
\hline September & 115 Unit \\
\hline
\end{tabular}

Sumber: Dealer Honda Astra Motor Kota Bengkulu Tahun 2019

Dengan melihat hasil wawancara diatas maka dapat disimpulkan bahwa penjualan unit sepeda motor tiap bulannya tidak stabil dimana ada penurunan penjualan pada bulan September. Hal ini disebabkan oleh kinerja karyawan menurun, apabila kinerja karyawan bagus maka target bisa dicapai, dan penjualan tiap bulanya bisa meningkat. Sedangkan di Dealer Honda Astra Motor Kota Bengkulu Kinerja karyawan menurun dikarnakan faktor stres dan beban kerja dalam bekerja untuk mencapai target penjualan, dan menghendel pekerjaan, pernyataan ini didapat pada saat mewawancarai karyawan di bidang marketing.

Stres merupakan salah satu penghambat kinerja karyawan. Stres adalah suatu kondisi dinamik yang didalamnya seorang individu dikonfrontasikan dengan suatu peluang. Termasuk kendala atau tuntutan yang di kaitkan dengan apa yang sangat diinginkannya dan yang dihasilkannya, dipersepsikan sebagai tidak pasti dan penting. Faktor penghambat lain, terhadap kinerja karyawan adalah adanya tekanan yang dirasakan oleh karyawan yang ditimbulkan oleh faktor organisasi. Dalam perkembangannya, ada beberapa faktor organisasi yang secara positif mampu menimbulkan stres ditingkat kerja. Diantaranya konflik, ketersaingan, beban kerja, situasi kerja, gaya kepemimpinan dan struktur organisasi. 
Stres pada karyawan pun juga dapat berdampak pada kinerja karyawan. Jika beban yang dirasakan karyawan terlalu berat, karyawaan akan mengalami hambatan dalam berfikir dan terganggunya kesehatan. Stres yang terlalu lama dialami oleh karyawan akan menjadi kerugian bagi perusahaan. Stres yang terlalu lama akan menyebabkan karyawan ingin keluar dari perusahaan, hal ini merupakan salah satu kerugian yang dapat timbul. Ada kalanya keluar masuk karyawan dapat berdampak positif, namun akan lebih banyak kerugian yang dialami. Stres merupakan keadaan yang wajar karena terbentuk pada diri manusia sebagai suatu respon dan merupakan bagian dari kehidupan sehari - hari dengan kesibukan dan beban kerja semakin bertambah. Stres dapat digambarkan sebagai perasaan tegang, gelisah, atau khawatir.

Beberapa hasil penelitian menjelaskan bahwa stres kerja berpengaruh terhadap kinerja karyawan diantaranya:

1. William A. Aresos, dkk (2018), dengan judul penelitian "Pengaruh Stres Kerja Terhadap Kinerja Karyawan”. Berdasarkan hasil penelitian, didapat hasil stres kerja berpengaruh negatif dan signifikan terhadap kinerja karyawan. Hal ini menjelaskan bahwa jika stres kerja meningkat maka akan mengurangi potensi kinerja karyawan dan jika sebaliknya stres kerja menurun maka akan meningkatkan potensi kinerja karyawan.

2. Chandra (2012) dalam penelitiannya menjelaskan bahwa stres kerja secara persial mempunyai pengaruh yang negatif dan signifikan terhadap kinerja karyawan. Ketika stres kerja rendah maka kinerja tinggi, demikian sebaliknya.

Menurut permendagri Nomor 12 tahun 2008, beban kerja adalah besaran pekerjaan yang harus dipikul oleh suatu jabatan atau unit organisasi dan merupakan hasil kali antara volume kerja dan normal waktu. Jika kemampuan pekerja lebih tinggi dari pada tuntutan pekerjaan maka akan muncul perasaan bosan, namun sebaliknya jika kemampuan pekerja lebih rendah dari pada tuntutan pekerjaan maka muncul kelelahan yang lebih. Oleh karena 
itu pembagian beban kerja yang tepat dan sesuai dengan kemampuan karyawan sangat penting untuk diperhatikan, karena dapat mempengaruhi kinerja karyawan dan juga pencapaian perusahaan.

Dari beberapa hasil penelitian menjelaskan bahwa beban kerja berpengaruh terhadap kinerja karyawan diantaranya yaitu:

1. Jeky K R Rolos (2018), dengan judul penelitian “ Pengaruh Beban Kerja Terhadap Kinerja Karyawan”. Berdasarkan hasil penelitiannya, didapat hasil beban kerja berpengaruh negatif dan signifikan terhadap kinerja karyawan. Hal ini menjelaskan bahwa jika beban kerja meningkat maka akan mengurangi potensi kinerja karyawan, dan jika sebaliknya beban kerja menurun maka akan meningkatkan potensi kinerja karyawan.

2. Lisnayetti dan Hasanbasri (2006), dalam penelitiannya menjelaskan bahwa beban kerja tinggi akan menyebabkan kurangnya kinerja, dimana dapat dijelaskan bahwa semakin tinggi beban kerja yang diterima seorang karyawan maka akan mempengaruhi kinerja dari karyawan tersebut.

Adanya harapan dan juga tuntutan kerja tinggi tersebut, tidak menutup kemungkinan bahwa perusahaan mengalami stres kerja, dan beban kerja yang dialami para karyawan Dealer Honda Astra Motor Kota Bengkulu mempunyai karyawan yang beragam, tempat asal yang berbeda dan juga adanya tuntutan tugas kerja yang tinggi memungkinkan timbulnya suatu stres kerja dan beban kerja yang dialami oleh karyawan dalam perusahaan tidak dapat dihindari. Sebagaimana hasil observasi awal diketahui bahwa Dealer Honda Astra Motor Kota Bengkulu sebagai perusahaan memiliki tujuan yang bagus dilengkapi dengan fasilitas memadai, sarana dan prasarana yang canggih, tetapi tanpa SDM yang baik, kemungkinan besar perusahaan tidak dapat mencapai tujuan.

SDM sebagai penggerak yang vital dalam suatu organisasi haruslah dikelola secara efektif dan efisien agar tujuan perusahaan lebih mudah untuk dicapai. Namun ternyata 
dalam mengelola dan mengatur karyawan tidaklah mudah karena masih ditemui adanya perbedaan pikiran, perasaan, status dan latar belakang yang berbeda dari karyawan yang dibawa dalam organisasi. Karyawan tidak dapat diatur dan dikuasai sepenuhnya dengan mudah. Oleh sebab itu, tentu perusahaan harus mampu dan bisa mengatasi stres kerja, dan beban kerja yang terjadi pada karyawan agar nantinya dapat meningkatkan kinerja karyawan.

Berdasarkan latar belakang di atas, penulis tertarik untuk mengadakan penelitian dengan judul "Pengaruh Stres Kerja, Dan Beban kerja Terhadap Kinerja Karyawan pada Dealer Honda Astra Motor Kota Bengkulu"

\subsection{Identifikasi masalah}

1. Kinerja karyawan pada Dealer Honda Astra Motor masih rendah.

2. Beban kerja karyawan terlalu tinggi.

3. Stres kerja pada karyawan masih sangat tinggi.

4. Adanya tuntutan dalam mencapai target dan tujuan perusahaan.

5. Adanya harapan dan juga tuntutan kerja tinggi menyebabkan terjadinya stres kerja dan beban kerja yang tidak dapat dihindari oleh Dealer Honda Astra Motor Kota Bengkulu.

\subsection{Batasan Masalah}

Permasalahan dalam penelitian ini dibatasi pada stres kerja, dan beban kerja dan berpengaruhnya terhadap kinerja karyawan pada Dealer Honda Astra Motor Kota Bengkulu.

\subsection{Rumusan Masalah}

Berdasarkan latar belakang masalah di atas maka penulis dapat merumuskan permasalahan dalam penelitian ini yaitu sebagai berikut: 
1. Apakah stres kerja berpengaruh terhadap kinerja karyawan Dealer Honda Astra Motor Kota Bengkulu?

2. Apakah beban kerja berpengaruh terhadap kinerja karyawan Dealer Honda Astra Motor Kota Bengkulu?

3. Apakah stres kerja dan beban kerja berpengaruh terhadap kinerja karyawan Dealer Honda Astra Motor Kota Bengkulu?

\subsection{Tujuan Penelitian}

Berdasarkan rumusan masalah di atas, tujuan penelitian ini adalah :

1. Untuk mengetahui pengaruh stres kerja terhadap kinerja karyawan pada Dealer Honda Astra Motor Kota Bengkulu.

2. Untuk mengetahui pengaruh beban kerja terhadap kinerja karyawan pada Dealer Honda Astra Motor Kota Bengkulu.

3. Untuk mengetahui pengaruh stres kerja, dan beban kerja terhadap kinerja karyawan Dealer Honda Astra Motor Kota Bengkulu

\subsection{Manfaat Penelitian}

1. Teoritis

Secara teoritis hasil penelitian ini diharapkan dapat menambah wawasan pengetahuan di bidang ke ilmuan maupun pengembangan ilmiah tentang stres kerja, dan beban kerja berpengarunya terhadap kinerja karyawan.

2. Praktis

Bagi perusahaan memberikan bahan pertimbangan kepada pihak perusahaan, khususnya mengenai pengaruh stres kerja dan beban kerja terhadap kinerja karyawan demi perbaikan dan perkembangan perusahaan diteliti.

a. Bagi peneliti diharapkan dapat menambah wawasan dan pengetahuan serta pemahaman penulis dalam bidang penelitian mulai dari pengumpulan data, pengelolaan data hingga penyajian dalam bentuk laporan. 
b. Bagi peneliti lain diharapkan menjadi bahan referensi pada penelitian selanjutnya yang berhubungan dengan manajemen sumber daya manusia.

c. Secara akademik penelitian ini memberikan kontribusi koleksi kepust dan referensi untuk mahasiswa lain di Fakultas Ekonomi Unveısitas Muhammadiyah Bengkulu.

\section{BAB II}

\section{STUDI PUSTAKA}

\subsection{Deskripsi Konseptual}

\subsubsection{Kinerja Karyawan}

\subsubsection{Pengertian Kinerja}

Kinerja merupakan pencapaian hasil kerja individu didalam sebuah organisasi. Kinerja dapat dinilai dengan membandingkan kerja individu dengan target yang telah ditentukan. Kinerja karyawan adalah hasil kerja secara kualitas dan kuantitas yang dicapai oleh seseorang karyawan dalam melaksanakan tugasnya sesuai dengan tanggung jawab yang diberikan kepadanya (Mangkunegara, 2009, Onsardi, O., 2019). Menurut Sedarmayanti (2009), kinerja atau performance diterjemahkan menjadi kinerja, juga berarti prestasi kerja, pelaksanaan kerja, pencapaian kerja, atau hasil kerja/unjuk kerja atau penampilan kerja. Kinerja mempunyai hubungan erat dengan masalah produktivitas karena merupakan indikator dalam menentukan bagai mana usaha untuk mencapai tingkat produktivitas yang tinggi dalam suatu organisasi. Sehubung dengan hal tersebut maka upaya untuk mengadakan penilaian terhadap kinerja disuatu organisasi merupakan hal penting. Lebih lanjut bahwa kinerja itu adalah unjuk kerja karyawan pada suatu perusahaan yang merupakan pencerminan loyalitas mereka dimana mereka bekerja (Asmawi, M., 2017, Anjani, R., 2019, Onsardi, O., 2018)

Suwanto dan Priansa (2011) menyatakan bahwa kinerja merupakan performance atau unjuk kerja. Kinerja dapat pula diartikan sebagai prestasi kerja atau pelaksanaan 
kerja atau hasil unjuk kerja. L.R Sayle dan Straus dalam Sedermayanti (2009), menyatakan bahwa standar kinerja perlu dirumuskan guna dijadikan tolak ukur dalam mengadakan perbandingan antara apa yang telah dilakukan dengan apa yang telah diharapkan, kaitannya dengan pekerjaan atau jabatan yang telah dipercayakan kepada seseorang. Suyadi Prawirosentono (2008) menyatakan kinerja adalah hasil kerja yang dapat dicapai oleh seseorang atau kelompok orang dalam suatu organisasi sesuai dengan wewenang dan tanggung jawab masing-masing dalam rangka upaya mencapai tujuan organisasi bersangkutan secara legal tidak melanggar hukum, dan sesuai dengan moral maupun etika. Muhammad Zainur (2010) mendefinisikan kinerja merupakan keseluruhan proses bekerja dari individu yang hasilnya dapat digunakan landasan untuk menentukan apakah pekerjaan individu tersebut baik atau sebaliknya. Kinerja juga merupakan keluaran yang dihasilkan oleh fungsi-fungsi atau indikator suatu pekerjaan atau suatu profesi dalam waktu tertentu (Wirawan, 2009).

Kamus besar bahasa Indonesia (2008) mendefinisikan karyawan adalah orang yang bekerja pada suatu lembaga (kantor, perusahaan, dan sebagainya) dengan mendapat gaji atau upah. Malayu Hasibuan (2003) mendefinisikan karyawan sebagai penjual jasa (pikiran dan tenaga) dan mendapatkan kompensasi yang besarnya telah ditetapkan terlebih dahulu. Menurut Bastian (2006), kinerja adalah gambaran pencapaian pelaksanaan suatu kegiatan, program, dan kebijaksanaan dalam meujudkan sasaran, tujuan, misi, dan visi organisasi.

Secara umum, kinerja merupakan prestasi yang dicapai oleh organisasi dalam periode tertentu. Lebih lanjut kinerja adalah hasil kerja secara kualitas dan kuantitas yang dicapai oleh seseorang karyawan dalam melaksanakan tugasnya sesuai dengan tanggung jawab yang diberikan kepadanya (Mangkunegara, 2005). Pendapat serupa juga dikemukakan oleh Melayu (2009) dalam Redha (2008), yang menyatakan bahwa kinerja adalah suatu hasil kerja yang dicapai seseorang dalam melaksanakan tugas-tugas yang 
dibebankan kepadanya atas kecakapan, pengalaman, dan kesungguhan, serta waktu. Pribadi yang produktif akan lebih kreatif dalam berhubungan dengan dunia sekitarnya dengan cara menciptakan suatu hasil kerja melalui kemampuan dan menggunakan pikiran serta perasaannya. Individu yang kreatif dapat dikatakan sebagai seseorang yang tinggi independensinya, inovatif dalam pendekatan masalah, terbuka terhadap sesuatu pengalaman baru yang lebih luas, ditandai dengan spontanitas, fleksibilitas, dan kompleksitas pandangan (Sedarmayanti, 2009).

Dari penjelasan diatas dapat disimpulkan bahwa kinerja adalah suatu pencapaian atau hasil kerja yang diperoleh dari seseorang dalam melaksanakan tugas dan tanggung jawab sesuai dengan kriteria yang telah ditetapkan oleh suatu organisasi dengan waktu yang telah ditetapkan. Novitasari (2003), mengemukakan bahwa tingkat sejauh mana keberhasilan seseorang dalam menyelesaikan pekerjaannya disebut "level of performance". Biasanya orang yang level performance-nya tinggi disebut sebagai orang yang produktif,dan sebaliknya orang yang levelnya tidak mencapai standar dikatakan sebagai tidak produktif atau performance-nya rendah. Dari beberapa penjelasan tentang pengertian kinerja diatas dapat disimpulkan bahwa kinerja adalah kemampuan yang ditunjukan oleh seseorang dalam melaksanakan tugas atau pekerjaannya. Kinerja dikatakan baik dan memuaskan apabila tujuan yang dicapai sesuai dengan standar yang ditetapkan.

\subsubsection{Faktor-Faktor Kinerja Karyawan}

Menurut Siti

Munafiah (2011) terdapat dua faktor yang mempengaruhi kinerja karyawan yaitu faktor internal dan faktor eksternal. Faktor internal adalah faktor-faktor yang berhubungan dengan sifat-sifat seseorang meliputi sikap, sifat kepribadian, sifat fisik, motivasi, umur, jenis kelamin, pendidikan, pengalaman kerja, latar belakang budaya, dan variabel personal lainya. Faktor eksternal adalah faktor-faktor yang mempengaruhi kinerja 
karyawan yang berasal dari lingkungan meliputi kebijakan organisasi, kepemimpinan, tindakan-tindakan rekan kerja, pengawasan, sistem upah, dan lingkungan sosial.

Menurut Timple dalam Uno (2012), ada enam faktor eksternal yang mempengaruhi kinerja karyawan, yaitu: lingkungan, perilaku manajemen, desain jabatan, penilaian kerja, umpan balik, serta balas jasa (upah/gaji). Prawirosentono (2008) mengungkapkan bahwa faktor yang mempengaruhi kinerja antara lain efektivitas dan efisiensi. Efektivitas berarti tujuan kelompok atau organisasi dapat dicapai sesuai dengan kebutuhan. Sementara efisiensi merupakan ukuran perbandingan antara rancangan rencana kebutuhan dengan kebutuhan yang sebenarnya.

Dapat diambil kesimpulan bahwa faktor-faktor yang mempengaruhi kinerja karyawan antara lain efisiensi dan efektivitas, meliputi penggunaan waktu kerja yang tepat, kecepatan dalam melaksanakan pekerjaan, tingkat ketidakhadiran, pelayanan yang maksimal, serta sanksi yang diberikan jika melakukan kesalahan dalam melaksanakan pekerjaan.

\subsubsection{Dimensi dan Indikator Kinerja Karyawan}

Menurut

Richard I. Handerson (1984) dalam Wirawan (2009) dimensi kinerja adalah kualitaskualitas atau wajah suatu pekerjaan atau aktivitas-aktivitas yang terjadi di tempat kerja yang konduktif terhadap pengukuran. Dimensi kinerja menyediakan alat untuk melukiskan keseluruhan cakupan aktivitas di tempat kerja. Sementara itu tanggung jawab dan kewajiban menyediakan suatu deskripsi depersonalisasi. Menurut Wirawan (2009) dimensi kinerja di kelompokkan menjadi tiga jenis yaitu, Hasil kerja, Perilaku kerja, Dan sifat pribadi yang berhubungan dengan pekerjaan. Indikator-indikator kinerja karyawan menurut Chester I.. Barnard dan Robert E. Quinn dalam Suyadi Prawirosentono (2008) adalah sebagai berikut:

a. Efektifitas dan efisiensi Bila suatu tujuan tertentu akhirnya dapat dicapai, kita boleh mengatakan bahwa kegiatan 
tersebut efektif. Apa bila akibat-akibat yang dicari dari kegiatan mempunyai nilai yang lebih penting dibandingkan hasil yang tercapai, sehingga mengakibatkan ketidak puasan walaupun efektif, hal ini disebut tidak efisien. Sebaliknya jika akibat yang tidak dicaricari tidak penting/remeh, maka kegiatan tersebut efisien. Sehubungan dengan itu kita dapat mengatakan sesuatu efektif bila mencapai tujuan tertentu. Dikatakan efisien bila hal itu memuaskan sebagai pendorong mencapai tujuan, terlepas apakah efektif atau tidak.

b. Otoritas dan tanggung jawab

Wewenang adalah hak seseorang untuk memberikan perintah kepada bawahan, sedangkan tanggung jawab adalah bagian yang tidak terpisah atau sebagai akibat dari kepemilikan wewenang tersebut. Bila ada wewenang berarti dengan sendirinya muncul tanggung jawab.

c. Disiplin

Disiplin meliputi ketaatan dan hormat terhadap perjanjian yang dibuat antara perusahaan dan karyawan. Disiplin juga berkaitan erat dengan sanksi yang perlu dijatuhkan kepada pihak yang melanggar.

d. Inisiatif

Inisiatif seseorang berkaitan dengan daya pikir kreatifitas dalam bentuk ide untuk merencanakan sesuatu yang berkaitan dengan tujuan organisasi.

\subsubsection{Stres Kerja}

\subsubsection{Pengertian Stres Kerja}

Tujuan yang dicapai perusahaan tidak akan terlepas dari peran dan adil setiap karyawan yang menjadi penggerak kehidupan organisasi, sehingga sudah selayaknya peran dari pemimpin para manajer perusahaan untuk dapat memahami kondisi para karyawannya, apabila karyawan terdapat beban masalah yang dapat menghambat kinerja perusahaan maka secepatnya pimpinan dapat mengurangi dan menyelesaikan beban karyawan tersebut, terutama mengenai stres kerja yang seharusnya dikelola dengan penuh 
berkesinambungan agar tidak menghambat jalannya kinerja perusahaan. Secara umum stres sering diartikan sebagai kondisi tegang yang tidak menyenangkan, karena seseorang secara subyektif merasa ada sesuatu yang membebaninya.

Menurut Siagian (2012) menyatakan bahwa stres kerja merupakan kondisi ketegangan yang berpengaruh terhadap emosi, jalan pikiran, dan kondisi fisik seseorang. Stres yang tidak diatasi dengan baik biasanya berakibat pada ketidak mampuan seseorang untuk berinteraksi secara positif dengan lingkungannya, baik dalam arti lingkungan pekerjaan maupun lingkungan luar pekerjaan. Suwanto dan Priansa (2011) menyatakan bahwa stres kerja adalah suatu kondisi dimana terdapat satu atau beberapa faktor ditempat kerja yang berinteraksi dengan pekerja sehingga mengganggu kondisi fisiologis, dan perilaku. Stres kerja akan muncul apabila terdapat kesenjangan antara kemampuan individu dengan tuntutan-tuntutan dari pekerjaanya. Menurut Ivancevich dalam Suwanto dan Priansa (2011) stres kerja merupakan respon adaptif, ditengahi oleh perbedaan individu yang merupakan suatu konsekuensi dari tindakan, situasi atau kejadian eksternal (lingkungan) yang menempatkan tuntutan fisik dan psikologis yang berlebihan terhadap seseorang. Menurut Desy (2002), stres kerja adalah suatu kondisi dimana satu atau beberapa faktor di tempat kerja berinteraksi dengan pekerja sedemikian rupa sehingga mengganggu keseimbangan fisiologik dan psikologik. faktor-faktor tersebut misalnya beban kerja yang telalu berat pekerjaan yang terlalu sedikit, hubungan atasan dengan bawahan yang kurang serasi dan peran yang tidak jelas. Stres merupakan hal yang lumrah dialami oleh setiap individu yang diakibatkan oleh faktor dari dalam maupun daru luar diri manusia itu sendiri. Stres bersifat fluktuasi kadang naik kadang turun tergantung dengan kondisi kerja yang dialami. Menurut Sedarmayanti (2011), stres sering diartikan sebagai kelebihan tuntutan atas kemempuan individu dalam memenuhi kebutuhan. Masalah yang terdapat dalam lingkungan keluarga, kegiatan sosial, pekerjaan dikantor, kegiatan di waktu senggang, maupun yang ada hubungannya dengan orang lain, 
dapat menimbulkan beban yang berlebihan. Menurut Yusuf (2004) istilah stres tidak dapat dipisahkan dari distress dan depresi, karna satu sama lainnya saling berkaitan. Stres merupakan reaksi fisik terhadap permasalahan kehidupan yang dialaminya dan apabila fungsi organ tubuh sampai terganggu dinamakan distress. Sedangkan depresi merupakan reaksi kejiwaan terhadap stres seseorang yang dialaminya. Romli mengemukakan bahwa stres merupakan suatu tekanan akibat bekerja juga akan mempengaruhi emosi, proses berpikir, dan kondisi fisik seseorang dimana tekanan itu berasal dari lingkungan pekerja tempat individu tersebut berada.

Menurut Agung (2008) stres adalah tuntutan-tuntutan eksternal yang mengenai seseorang, misalnya obyek-obyek dalam lingkungan atau suatu stimulus yang secara obyektif adalah berbahaya. Stres juga bisa diartikan sebagai tekanan, ketegangan atau gangguan yang tidak menyenangkan yang berasal dari luar diri seseorang. Menurut Robbins (2006) stres kerja karyawan adalah kondisi yang muncul dari interaksi antara manusia dan pekerjaan serta di karakteristikkan oleh perubahan manusia yang memaksa mereka untuk menyimpang dari fungsi normal mereka.

Suprihanto dkk (2003) mengatakan bahwa dari sudut pandang organisasi, manajemen mungkin tidak khawatir jika karyawannya mengalami stres yang ringan. Alasannya karena pada tingkat stres tertentu akan memberikan akibat positif, karena hal ini akan mendesak mereka untuk melakukan tugas lebih baik.

\subsubsection{Jenis-Jenis dan Faktor penyebab Stres Kerja}

Salye dalam Jaza Anil Chusna (2010) mengatakan bahwa terdapat dua jenis stres, yaitu eustres dan distres.

a. Eustres, yaitu hasil dari respon terhadap stres yang bersifat sehat,positif, dan konstruktif (bersifat membangun). Ketika tubuh mampu menggunakan stres yang dialami untuk membantu melewati sebuah hambatan dan meningkatkan performa, stres tersebut bersifat positif, sehat, dan menantang ( Walker.J, 2002) 
b. Distres, yaitu hasil dari respon terhadap stres yang bersifat tidak sehat, negatif, dan destruktif (bersifat merusak ). Ketika seseorang mengalami distres, orang tersebut akan cendrung bereaksi secara berlebihan, bingung, dan tidak dapat berperforma secara maksimal (Wilker.J, 2002).

Menurut Sunyoto (2013), stres dapat disebabkan oleh beberapa faktor yaitu:

a. Penyebab fisik (kebisingan dan kelelahan).

Kebisingan terus menerus dapat menjadi sumber stresbagi banyak orang. Namun perlu diketahui bahwa terlalu tegang juga menyebabkan hal yang sama. Selain kebisingan kelelahan juga dapat menyebabkan stres karena kemampuan untuk bekerja menurun. Kemampuan bekerja menurun menyebabkan prestasi menurun dan tanpa disadari menimbulkan stres, pergeseran prestasi, mengubah pola kerja yang terus menerus dapat menimbulkan stres. Hal ini disebabkan karena seseorang karyawan sudah terbiasa dengan pola kerja yang lama dan sudah terbiasa dengan kebiasaan-kebiasaan lama. Kelelahan disebabkan oleh perubahan waktu sehingga mempengaruhi irama tubuh seseorang. Untuk itu disarankan bagi mereka yang baru menempuh perjalanan jauh dimana terdapat perbedaan waktu agar beristirahat minimal 24 jam sebelum melakukan aktivitas.

b. Suhu dan Kelembapan.

Bekerja dalam ruangan yang suhunya terlalu tinggi dapat mempengaruhi tingkat prestasi karyawan. Suhu yang tinggi harus dapat ditoleransi dengan kelembapan yang renda.

c. Beban kerja.

Beban kerja yang terlalu banyak dapat menyebabkan ketegangan dalam diri seseorang sehingga menimbulkan stres. Hal ini bisa disebabkan oleh tingkat keahlian yang dituntut terlalu tinggi, Volume kerja mungkin terlalu banyak dan sebagainya. 
d. Sifat pekerjaan.

situasi baru dan asing. Menghadapi situasi baru dan asing dalam pekerjaan atau organisasi, seseorang akan terasa sangat tertekan sehingga dapat menimbulkan stres. Selain itu ancaman pribadi juga mempengaruhi, suatu tingkat kontrol (pengawasan) yang terlalu ketat dari atasan menyebabkan seseorang terasa terancam kebebasannya. Stres bisa terjadi ketidak mampuan seseorang untuk memacu pekerjaanya. Selain kurang kejelasan terhadap apa yang harus dikerjakan akan menimbulkan kebingungan dan keraguan bagi seseorang untuk melaksanakan suatu pekerjaan. Standar kerja yang tidak jelas dapat membuat karyawan tidak puas karena mereka tidak pernah tahu prestasi mereka. Disamping itu, standar kerja yang tidak jelas juga dapat dipergunakan untuk menekan karyawan.

e. Kebebasan.

Kebebasan yang diberikan kepada karyawan belum tentu merupakan hal yang menyenangkan. Ada sebagian karyawan justru dengan adanya kebebasan membuat mereka tidak merasa ketidakpastian dan ketidakmampuan dalam bertindak. Hal itu dapat merupakan sumber stres bagi seseorang.

f. Kesulitan

Kesulitan-kesulitan yang dialami dirumah, seperti ketidakcocokan suami istri. Masalah keuangan, perceraian dapat dapat mempengaruhi prestasi kerja. Hal seperti ini merupakan sumber stres bagi seseorang.

\subsubsection{Sumber-Sumber Stres}

Menurut siagian (2012), pada dasarnya berbagai sumber stres dapat digolongkan pada yang berasal dari pekerjaan dan dari luar pekerjaan seseorang. Berbagai hal dapat menjadi sumber stres yang berasal daru pekerjapun dapat beraneka ragam seperti beban tugas yang terlalu berat, desakan waktu, iklim kerja yang menimbulkan rasa yang tidak 
aman, kurangnya informasi dari umpan balik tentang prestasi kerja seseorang, ketidakseimbangan antara wewenang dan tanggung jawab, ketidak jelasan peranan karyawan dalam keseluruhan kegiatan organisasi, prustasi yang ditimbulkan oleh intervensi pihak lain yang terlalu sering sehingga seseorang merasa terganggu kosentrasinya, konflik antara karyawan dengan pihak dalam dan luar kelompok kerjanya, perbedaan system nilai yang dianut oleh karyawan dan yang dianut oleh organisasi dan perubahan yag terjadi yang pada umumnya memang menimbulkan rasa ketidak pastian.

Suwanto dan Priansa (2011) membagi sumber stres kerja dari lingkungan kerja sebagai berikut:

1. Stres yang bersumber dari lingkungan fisik, sumber stres ini mengacu pada kondisi fisik dalam lingkungan dimana pekerja harus beradaptasi untuk memelihara keseimbangan dirinya. Stres yang bersumber dari lingkungan fisik disini, diantaranya adalah: kondisi penerangan ditempat kerja, tingkat kebisingan, keluasan wilayah kerja.

2. Stres yang bersumber dari tingkatan individu, yang dimaksud dengan sumber ini adalah stres yang berkaitan dengan peran-peran yang dimainkan dan tugas-tugas yang harus diselesaikan sehubung dengan posisi seseorang di lingkungan kerjanya dan yang termasuk dalam sumber stres kerja ini adalah:

a. Konflik Peran

kombinasi dari harapandan tuntutan yang diberikan kepada pegawai atau anggota lain dalam organisasi yang menimbulkan tekanan disebut tekanan peran.

b. Peran yang racu/tidak jelas

ketidakjelasan seseorang mengenai peran yang harus dilaksanakannya, baik yang berkaitan dengan tugas yang harus ia lakukan maupun dengan tanggung jawab sehubungan dengan posisinya.

c. Beban kerja yang berlebihan 
Beban kerja ini dapat bersifat kuantitatif maupun kualitatif. Disebut kuantitatif jika seseorang menghayati terlalu banyak pekerjaan yang harus diselesaikan, atau karena keterbatasan waktu untuk menyelesaikan pekerjaan yang diberikan.

d. Tanggung jawab kepada orang lain tanggung jawab disini dapat meliputi tanggung jawab terhadap orang lain atau hal-hal lain. Dalam banyak kasus tangung jawab terhadap orang lain lebih potensial berbagai sumber stres.

e. Kesempatan untuk mengembangkan karir

Sumber stres ini adalah aspek-aspek sebagai hasil dari interaksi antara individu dengan lingkungan organisasi yang mempengaruhi persepsi sesorang terhadap kualitas dan pengembangan karirnya.

3. Stres kerja yang bersumber dari kelompok dan organisasi

a. Stres yang bersumber dari kelompok

stres disini bersumber dari hasil interaksi individu-individu dalam suatu kelompok yang disebabkan perbedaan-perbedaan diantara mereka

b. Stres yang bersumber dari organisasi

stres ini timbul dari keinginan-keinginan organisasi atau lembaga sehubungan dengan pencapaian tujuan organisasi atau lembaga tersebut. Mecam-macam stres yang bersumber dari organisasi, antara lain:

1) Iklim organisasi. Suatu organisasi tidak hanya memiliki perbedaan dalam struktur fisik namun juga dalam sikap dan tingkah laku pekerjaannya. Interaksi antara individu,struktur kebijaksanaan dan tujuan organisasi secara umum disebut iklim organisasi yang bersangkutan.

2) Struktur organisasi. Stres yang timbul oleh bentuk struktur organisasi yang berlaku di lembaga yang bersangkutan. 
3) Teritorial organisasi. Istilah yang menggambarkan ruang pribadi atau arena kegiatan seseorang, tempat dimana mereka bekerja atau begurau.

4) Teknologi. Yang dimaksud dengan teknologi disini adalah cara-cara organisasi mengubah sumber-sumber input menjadi hasil output yang diinginkan.

5) Pengaruh pimpinan salah satu faktor yang data mempengaruhi akktivitas pekerjaan, iklim dan kelompok adalah bagaimana pimpinannya.

\subsubsection{Indikator Stres Kerja}

Indikator Stres Kerja menurut Robbins ( 2006) yaitu:

a. Tuntutan tugas

Tuntutan tugas adalah faktor yang terkait dengan pekerjaan seseorang. Tuntutan tersebut meliputi desain pekerjaan individual, kondisi kerja,dan tata letak fisik pekerjaan. Sebagai contoh, bekerja diruangan yang terlalu sesak atau di lokasi yang selalu terganggu oleh suara bising dapat meningkatkan kecemasan dan stres.

b. Tuntutan peran

Bekerja dapat menjadi pengalaman yang sangat mengesankan, bagi banyak orang pekerjaan merupakan bagian yang cukup besar dari identitas mereka, namun terkadang pekkerjaan merasa terganggu apabila muncul permasalahan pada pekerjaan tersebut. Sebagai contoh bila konflik rekan kerja timbul, konflik ini akan menjadi beban psikologis dalam pekerjaan beban tersebut dapat berubah menjadi depresi.

c. Tuntutan antar pribadi

Kondisi kerja yang berpotensi menimbulkan stres kerja salah satunya adalah hubungan interpersonal yang tidak kondusif atau tuntutan antar pribadi yang dapat memicu konflik. Ini misalnya terlalu banyak terlalu banyak konflik antar individu, kurang bersahabat antar sesama, dan lain sebagainya.

d. Struktur organisasi 
Adalah sistem tugas, alur kerja, hubungan pelaporan, dan saluran komunikasi yang dikaitkan secara bersama dalam pekerjaaan individual maupun kelompok.

e. Kepemimpinan organisasi

Kepemimpinan menjadi salah satu faktor penting bagi keberhasilan sebuah organisasi, untuk itu ada beberapa sikap kepemimpinan dalam organisasi yang perlu diterapkan oleh seorang pemimpin, diantaranya menjalin kedekatan dengan anak buah.

\subsubsection{Beban Kerja}

\subsubsection{Pengertian Beban Kerja}

Beban kerja adalah sekumpulan atau sejumlah kegiatan yang harus diselesaikan oleh suatu unit organisasi atau pemegang jabatan dalam jangka waktu tertentu Sunarso (2010). Permendagri No. 12/2008 menyatakan bahwa beban kerja adalah besaran pekerjaan yang harus dipikul oleh suatu jabatan/unit organisasi dan merupakan hasil kali antara volume kerja dan norma waktu. Jika kemampuan pekerja lebih tinggi dari pada tuntutan pekerjaan,akan muncul perasaan bosan. Namun sebaliknya, jika kemampuan pekerja lebih rendah dari pada tuntutan pekerjaan, maka akan muncul kelelahan yang lebih. Beban kerja yang dibebankan kepada karyawan dapat dikategorikan kedalam tiga kondisi, yaitu beban kerja yang sesuai standar, beban kerja yang terlalu tinggi (over capacity) dan beban kerja yang terlalu rendah (under capacity).

Robbins (2003), menyatakan bahwa positif negatifnya beban kerja merupakan masalah persepsi. Persepsi didefinisikan sebagai suatu proses dimana individu mengorganisasikan dan menafsirkan kesan indera mereka agar memberi makna kepada lingkungan mereka (Robbins, 2007). Persepsi terhadap beban kerja berkaitan dengan faktor atribut peran dan pekerjaan. Hal ini dikarnakan persepsi terhadap beban kerja merupakan hal yang erat hubungannya dengan suatu pekerjaan, dimana individu memberikan penilaian mengenai sejumlah tuntutan atau kegiatan yang membutuhkan 
aktivitas mental dan fisik yang harus ia selesaikan dalam waktu tertentu

Gibson (2009) menyatakan bahwa beban kerja adalah keharusan mengerjakan terlalu banyak tugas atau penyediaan waktu yang tidak cukup menyelesaikan tugasnya. Selanjutnya berdasarkan Undang-Undang Kesehatan Nomor 36 tahun 2009 bahwa beban kerja adalah besaran pekerjaan yang harus dipikul oleh suatu jabatan/unit organisasi dan merupakan hasil kali antara jumlah pekerjaan dengan waktu. Setiap pekerja dapat bekerja dapat bekerja secara sehat tanpa membahayakan dirinya sendiri maupun masyarakat di sekelilingnya, untuk itu perlu dilakukan upaya penyerasian antara kapasitas kerja, beban kerja dan lingkungan kerja, beban kerja agar diperoleh produktivitas kerja yang optimal.

\subsubsection{Faktor-faktor yang Mempengaruhi Beban Kerja}

Menurut Gibson (2009), faktor-faktor yang mempengaruhi beban kerja, yaitu :

a. Time pressure (tekanan waktu)

Secara umum dalam hal tertentu waktu akhir (dead line) justru dapat meningkatkan motivasi dan menghasilkan prestasi kerja yang tinggi, namun desakan waktu juga dapat menjadi beban kerja berlebihan kuantitatif ketika hal ini mengakibatkan munculnya banyak kesalahan atau kondisi kesehatan seseorang berkurang.

b. Jadwal kerja atau jam kerja

Jumlah waktu untuk melakukan kerja berkontribusi terhadap pengalaman akan tuntutan kerja, yang merupakan salah satu faktor penyebab stres dilingkungan kerja. Hal ini berhubungan dengan penyesuaian waktu antara pekerjaan dan keluarga terutama jika pasangan suami-istri sama- sama bekerja. Jadwal kerja standar adalah 8 jam sehari selama seminggu. Untuk jadwal kerja ada tiga tipe, yaitu : night shift, long shift, flexible work schendule. Dari ketiga tipe jadwal kerja tersebut, long shift, dan night shift, dapat berpengaruh terhadap kesehatan tubuh seseorang. 
c. Role ambiguity dan role conflict role ambiguity kemenduaan peran dan role conflict atau konflik peran dapat mempengaruhi prestasi seseorang terhadap beban kerjanya. Hal ini dapat sebagai hal yang mengancam atau menantang.

d. Kebisingan, dapat mempengaruhi pekerja dalam hal kesehatan dan performancenya. Pekerja yang kondusif kerjanya sangat bising dapat mempengaruhi efektifitas kerjanya dalam menyelesaikan tugasnya, dimana dapat mengganggu kosentrasi dan otomatis menggangu pencapaian tugas sehingga dapat dipastikan semakin memperberat beban kerjanya.

e. Information overload,

Banyaknya informasi yang masuk dan diserap pekerja dalam waktu yang bersamaan dapat menyebabkan beban kerja semakin berat. Kemajemukan teknologi dan pengunaan fasilitas kerja yang serba canggih membutuhkan adaptasi tersendiri dari pekerja. Semakin kompleks informasi yang diterima, dimana masing-masing menuntut kosenkuensi yang berbeda dapat mempengaruhi proses pembelajaran pekerja dan efek lanjutannya. Bagi kesehatan jika tidak tertangani dengan baik.

f. Temperature extremes atau heat overload. Sama halnya dengan kebisingan, faktor kondisi kerja yang berisiko seperti tingginya temperatur dalam ruangan juga berdampak pada kesehatan. Hal ini utamanya jika kondisi tersebut berlangsung lama dan tidak ada peralatan pengamannya.

\section{g. Repetitive action}

Banyaknya pekerjaan yang membutuhkan aksi tubuh secara berulang, seperti pekerja yang menggunakan komputer dan menghabiskan sebagian waktunya dengan mengetik, atau pekerja assembly line yang harus mengoperasikan mesin dengan prosedur yang sama setiap waktu atau dimana banyak terjadi pengulangan gerak akan timbul rasa bosan, rasa monoton, yang pada akirnya dapat 
menghasilkan berkurangnya perhatian dan secara potensial membahayakan jika tenaga gagal untuk bertindak tepat dalam keadaan darurat. Aspek ergonomi dan lay out tempat kerja.

h. Tanggung jawab

Setiap jenis tanggung jawab (responsibility) dapat merupakan beban kerja bagi sebagian orang. Jenis-jenis tangung jawab yang berbeda, berbeda pula fungsinya sebagai penekan. Hasil penelitian menunjukkan bahwa tanggung jawab terhadap orang menimbulkan tekanan yang berhubungan dengan pekerjaan. Sebaliknya semakin banyak tanggung jawab terhadap baran, semakin rendah indikator tekanan yang berhubungan dengan pekerjaan.

\subsubsection{Indikator Beban Kerja.}

Menurut Putra (2012), ada 4 indikator dalam beban kerja yaitu:

1. Target yang harus dicapai

Pandangan individu mengenai besarnya target kerja yang diberikan untuk menyelesaikan pekerjaannya. Pandangan mengenai hasil kerja yang harus diselesaikan dalam jangka waktu tertentu.

2. Kondisi pekerjaan

Mencangkup tentang bagaimana pandangan yang dimiliki oleh individu mengenai kondisi pekerjaannya, misal mengambil keputusan dengan cepat pada saat pengerjaan barang, serta mengatasi kejadian yang tak terduga seperti melakukan pekerjaan ekstra diluar waktu yang telah ditentukan.

3. Penggunaan waktu

Kerja waktu yang digunakan dalam kegiatan-kegiatan yang langsung berhubungan dengan produksi (waktu lingkaran, atau waktu baku atau dasar).

4. Standar pekerjaan 
Kesan yang dimiliki oleh individu mengenai pekerjaannya, misalnya pekerjaan yang timbul mengenai beban kerja yang harus diselesaikan dalam jangka waktu tertentu.

\subsubsection{Pengaruh Stres Kerja Terhadap Kinerja Karyawan.}

Mangkunegara (2008) mengemukakan stres kerja sebagai perasaan tegang dan tertekan yang dialami ketika tuntutan yang dihadapkan melebihi kekuatan yang ada pada diri kita, semakin tinggi stres kerja yang di alami karyawan maka akan berpengaruh terhadap kinerja dan menurunya potensi karyawan. Stres kerja secara persial mempunyai pengaruh yang negatif dan signifikan terhadap kinerja karyawan berdasarkan penelitian Chandra (2012). Menjelaskan bahwa stres kerja berpengaruh negatif signifikan terhadap kinerja karyawan. Dengan demikian apa bila terjadi peningkatan stres kerja, akan menimbulkan penurunan kinerja karyawan. Begitu pula sebaliknya, apabila terjadi penurunan stres kerja akan menimbulkan peningkatan kinerja kerja karyawan.

Pengaruh stres kerja terhadap kinerja karyawan adalah negatif,artinya bahwa ketika stres kerja rendah maka kinerja karyawan akan meningkat, dan demikian pula sebaliknya. Chiou (2011), menyatakan bahwa stres kerja bersifat mengganngu kinerja, dan semakin tinggi stres kerja maka semakin tinggi pula tingkat gangguan pada kinerja karyawan. Selain itu, Shahu dan Gole (2008), juga menyatakan bahwa stres merupakan kondisi mental dan fisik yang berpengaruh terhadap produktifitas kerja, efektivitas, kesehatan karyawan, dan kualitas kerja. Apabila seorang karyawan merasa stres dalam bekerja dan tidak didukung dengan kesehatan fisik yang baik, tentunya akan mengakibatkan kerja menjadi tidak fokus oleh gangguan-gangguan tersebut, hal ini berdampak akan menurunnya kinerja karyawan. Pendapat tersebut secara jelas menunjukkan bahwa terdapat korelasi negatif antara stres kerja dan kinerja dimana ketika stres kerja tinggi maka kinerja semakin rendah.

\subsubsection{Pengaruh Beban Kerja Terhadap Kinerja Karyawan}


Menurut Lisnayetti (2006), beban kerja tinggi akan menyebabkan kurangnya kinerja, dimana dapat dijelaskan bahwa semakin tinggi beban kerja yang diterima seorang karyawan akan mempengaruhi kinerja dari karyawan tersebut. Kahneman dalam Warr (2002), menjelaskan bahwa beban kerja adalah suatu kompetensi dari suatu sumber mental yang terbatas salah satu penyebab menurunnya performa dari beban kerja adalah keharusan untuk mengambil dua atau lebih tugas-tugas yang harus dikerjakan secara bersamaan. Semakin banyaknya permintaan untuk melaksanakna tugas-tugas tersebut maka semakin berkurangnya performa dalam bekerja, hal ini akan menyebabkan kinerja karyawan menurun.

Menurut Jeki K R Rolos, dkk (2018), berdasarkan hasil penelitiannya beban kerja berpengaruh negatif terhadap kinerja karyawan. Hal ini menjelaskan bahwa jika beban kerja meningkat maka akan mengurangi potensi kinerja karyawan, dan jika sebaliknya beban kerja menurun maka akan meningkatkan potensi kinerja karyawan. Kinerja merupakan suatu aspek yang dapat digunakan dalam mengukur kinerja karyawan yang tentunya kinerja tersebut memiliki indikator-indikator khusus seperti waktu, seseorang dapat diukur seberapa tinggi kinerjanya dengan diberikan pekerjaan yang hasilnya dihitung berapa lama karyawan tersebut mengerjakan pekerjaannya.

Kinerja artinya setiap karyawan melakukan tugas pekerjaannya yang dipercayakan untuk dikerjakan dan dipertanggung jawabkan oleh satuan organisasi atau seorang karyawan tertentu sesuai dengan kemampuan dan kesanggupan sehingga efektivitas kerja akan berhasil dengan baik. Dalam persepsi karyawan, beban kerja merupakan penilaian individu mengenai sejumlah tuntutan tugas atau kegiatan yang membutuhkan aktivitas mental misalnya untu mengingat hal-hal yang diperlukan, kosentrasi, mendeteksi permasalahan, mengatasi kejadian yang tak terduga dan membuat keputusan dengan cepat yang berkaitan dengan pekerjaan dan kekuatan fisik untuk mengangkat apa yang harus diselesaikan dalam jangka waktu tertentu apa bila individu 
tersebut memiliki persepsi yang positif maka merekan akan menganggap beban kerja sebagai tantangan dalam bekerja sehingga mereka lebih bersungguh- sungguh dalam bekerja dan menghasilkan sesuatu yang bermanfaat bagi dirinya maupun perusahaan tempat bekerja. Sebaliknya jika persepsi negatif yang muncul maka beban kerja dianggap sebagai tekanan kerja sehingga dapat mempengaruhi kinerja individu,memiliki dampak negatif bagi dirinya maupun perusahaan tempat bekerja.

\subsection{Hasil Penelitian Yang Relevan}

1. Riny Chandra (2017), dengan judul penelitian "Pengaruh Beban Kerja, dan Stres Kerja Terhadap Kinerja Karyawan”. Berdasarkan hasil penelitiannya hasil persamaan regresi linier berganda diketahui beban kerja berpengaruh negatif terhadap kinerja karyawan pada PT. Auto Cntral Finance Cabang Langsa. Hasil Uji T diperoleh pada variabel beban kerja perpengaruh tidak signifikan terhadap kinerja, dan stres kerja berpengaruh signifikan terhadap kinerja. Helanjutnya hasil uji F diketahui bahwa secara bersama- sama beban kerja dan stres kerja berpengaruh signifikan terhadap kinerja karyawan. Hasil koefisien determinasi diperoleh 0,263 atau 26,3\% dipengaruhi oleh kinerja. Dan sisanya sebesar 73, 7\% dipengarruhi dipengaruhi oleh variabel lain.

2. Jeky K R Rolos, dkk (2018), dengan judul penelitian “ pengaruh Beban Kerja Terhadap Kinerja Karyawa". Dari hasil analisis koefisien dterminan, dapat diketahui bahwa nilai $\mathrm{R}$ Square adalah sebesar 0,171 dan apabila diubah dalam bentuk persen (\%) maka nilainya menjadi $17,1 \%$ yang berarti pengaruh beban kerja (X) terhadap kinerja karyawan (Y) adalah sebesar 17,1\% sedangkan $82,9 \%$ dipengaruhi oleh variabel lain. Dan disimpulkan bahwa beban kerja berpengaruh terhadap kinerja karyawan. Dengan total pengaruh sebesar $17,1 \%$. 
3. Bagus Setiawan Sutowoputro (2016), dengan judul penelitian “ pengaruh beban kerja dan stres kerja terhadap kinerja karyawan PT Budi Sehat di Surakarta" berdasarkan hasil penelitian persamaan regresi yang diperoleh adalah $\mathrm{Y}=39,745$ 0,500X1. Nilai $t$ hitung sebesar 4,150 dengan p-value 0,000. Hasil ini menunjukkan bahwa variabel beban kerja (X1) pada saat konstan (tetap) berada pada posisi 39,745, sedangkan apabila variabel ini diangkat satu point maka dapat menurunkan variabel kinerja karyawan sebesar 0,500. Dilihat dari p-value diketahui lebih kecil dari $0,05(0,000<0,05)$ sehingga menunjukkan bahwa variabel beban kerja berpengaruh negatif dan signifikan terhadap kinerja karyawan PT. Budi Sehat di Surakarta. Dilihat dari p-value diketahui lebih kecil dari $0,05 \quad(0,001<0,05)$ sehingga menunjukkan bahwa fariabel stres kerja berpengaruh negative dan signifikan terhadap kinerja karyawan PT. Budi Sehat di Surakarta.

4. Rachel Natalya Massie, dkk (2018), dengan judul penelitian “ pengaruh stres kerja terhadap kinerja karyawan pada Kantor Pengelola It Center Manado. Hasil penelitiannya dari hasil analisis korelasi antara stres kerja dan kinerja karyawan,dapat dilihat bahwa pearson correlation $-0,390$ dan nilai signifikasi $0,027<0,05$ yang artinya hasil angka variabel stres kerja dan variabel kinerja karyawan berkorelasi rendah dan terbalik. Artinya kalau stres kerja tinggi maka kinerja karyawan menurun, dan jika stres kerja menurun maka kinerja karyawan meningkat. Berdasarkan hasil penelitian yang didapat stres kerja berpengaruh negative dan signifikan terhadap kinerja karyawan pada Kantor Pengelola It Center Manado, hal ini menjelaskan bahwa jika stres kerja meningkat maka mengurangi potensi kerja karyawan.

5. Celine Fonkeng (2018), with the research title "effects of job-stress on employee performance in an enterprise A microfinance institution in Cameroon" The 
results of his research showed that work stress depressed employees and negatively affected their performance is greater than employees must be free from work stress so that performance increases. There are many stress factors experinced by employees of this institution, it is evident that too much stress negatively affects employee productivity. In hypothesis, stress has a negative impact on employee performance, when it reaches a cartain undesirable poit, “Celine Fonkeng ( 2018), dengan judul penelitian “ pengaruh stres kerja terhadap kinerja karyawan pada PT Usaha Lembaga Keuangan Mikro di Kamerun”. Hasil penelitiannya menunjukkan stres kerja membuat karyawan tertekan dan berpengaruh negatif terhadap kinerja mereka, untuk itu karyawan keuangan mikro harus bebas dari stres kerja agar kinerja karyawan meningkat. Ada banyak faktor stres yang dialami oleh karyawan lembaga ini terbukti bahwa stres berpengaruh negatif terhadap produktivitas karyawan, dalam hipotesis stres memiliki dampak negatif pada kinerja karyawan ketika tidak mencapai titi tertentu”.

6. Resky Rahayu (2017), dengan judul penelitian “ pengaruh stres kerja terhadap kinerja karyawan pada PT Telesindo Shop Cabang Makasar”. Berdasarkan hasil penelitiannya dari hasil pengujian persial (uji $\mathrm{T}$ ) antara variabel stres individu dengan variabel kinerja karyawan menunjukkan nilai t hitung sebesar $1.195<1,667$ koefisien regresi sebesar 0,076 dan nilai probalitas sebesar 0,236 yang lebih besar dari 0,05 hal ini berarti bahwa stres individu berpengaruh negatif dan tidak signifikan terhadap kinerja karyawan sehingga hipotesis ditolak.

7. Arie fajriani, dkk (2015), dengan judul penelitian “ pengaruh beban pekerjaan terhadap kinerja karyawan: Efek Mediasi Burnout”. Hipotesis pertama yang diajukan dalam penelitian ini menyatakan bahwa beban pekerjaan berpengaruh terhadap kinerja karyawan, pada tabel 2 di peroleh nilai koefisien sebesar 0,317 dan nilai signifikansi (sig) sebesar 0,00 lebih kecil dari $p$ value $(0,05)$.hasil 
penelitian menunjukkan bahwa terdapat pengaruh mediasi sebagian antara beban kerja dengan kinerja karyawan. Karyawan yang memiliki beban kerja berlebihan akan memicu timbulnya kejenuhan (burnout), yang pada akhirnya akan menurunkan kinerja.

8. Frengky Sanjaya (2012), dengan judul penelitian “ pengaruh stres kerja terhadap kinerja karyawan dengan kecerdasan emosi sebagai emosi sebagai moderating variable PT. Summit Oto Finance Kudus “. Hasil penelitiannya menunjukkan hipotesis diuji menggunakan analisis regresi sederhana, nilai $t$ hitung $\mathrm{X} 1$ sebesar 5.400 dengan nilai signifikansi 0,000 jauh dibawah 0,05 . Hal ini menunjukkan bahwa hipotesis 1 yang menyatakan stres kerja berpengaruh terhadap kinerja, diterima. Pada penelitian ini ditemukan bahwa stres kerja berpengaruh negatif dan signifikan terhadap kinerja karyawan, ketika stres kerja tinggi maka kinerja karyawan marketing dan collection akan rendah, ketika stres kerja karyawan rendah maka kinerja karyawan akan tinggi.

9. Riyan Sisiawan Putra (2018), dengan judul penelitian “ pengaruh beban kerja terhadap kinerja karyawan Universitas Nahdlatul Ulama Surabaya”. Dari hasil penelitiannya disimpulkan pengaruh beban kerja terhadap kinerja karyawan berpengaruh negatif dan signifikan. Sehingga H1 diterima berdasarkan hasil estimasi inner weigh untuk pengaruh beban kerja terhadap kinerja menunjukkan hasil koefisien estimasi sebesar -0,60069 dengan t-statistik sebesar 3,10833 1.96\% sehingga dapat disimpulkan bahwa beban kerja berpengaruh negatif dan signifikan terhadap kinerja.

\subsection{Kerangka Teoritik}

Kerangka

Teoritik adalah sitematika berfikir peneliti dalam penelitian ini, hal tersebut digambarkan berikut ini : 


\section{Gambar 2.1}

\section{Kerangka Pemikiran Teoritik}

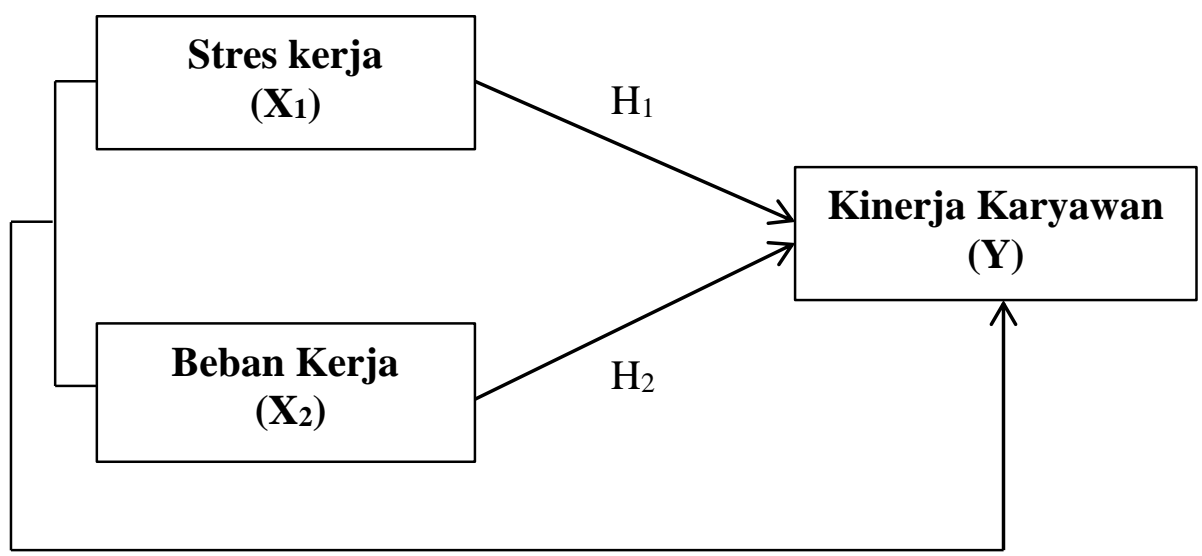

$\mathrm{H}_{3}$

Keterangan :

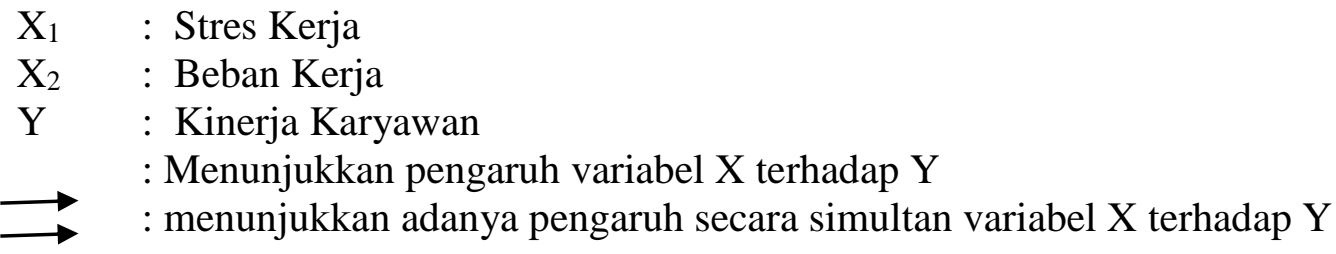

\subsection{Definisi Operasional}

Definisi operasional variabel dapat dilihat pada tabel berikut ini:

tabel 2.1

Definisi Operasional Variabel

\begin{tabular}{|c|c|c|c|c|c|}
\hline No & Variabel & Definisi & Indikator & Alat ukur & $\begin{array}{l}\text { Skala } \\
\text { Ukur }\end{array}$ \\
\hline 1. & $\begin{array}{l}\text { Kinerja } \\
\text { Karyawan } \\
\text { (Y) }\end{array}$ & $\begin{array}{l}\text { Kinerja karyawan } \\
\text { adalah hasil kerja } \\
\text { secara kualitas dan } \\
\text { kuantitas yang } \\
\text { dicapai oleh seorang } \\
\text { karyawan dalam } \\
\text { melaksanakan } \\
\text { tugasnya,sesuai } \\
\text { dengan tanggung } \\
\text { jawab yang } \\
\text { diberikan } \\
\text { kepadanya. }\end{array}$ & $\begin{array}{l}\text { 1. Efektivitas } \\
\text { dan efisiensi } \\
\text { 2. Otoritas dan } \\
\text { tanggung } \\
\text { jawab } \\
\text { 3. Disiplin } \\
\text { 4. Inisiatif }\end{array}$ & Kuisioner & Ordinal \\
\hline 2. & $\begin{array}{l}\text { Stres Kerja } \\
\left(\mathrm{X}_{1}\right)\end{array}$ & $\begin{array}{l}\text { stres kerja adalah } \\
\text { suatu keadaan } \\
\text { tertekan,baik secara } \\
\text { fisik maupun }\end{array}$ & $\begin{array}{l}\text { 1. Tuntutan } \\
\text { tugas } \\
\text { 2. tuntutan } \\
\text { peran }\end{array}$ & Kuisioner & Ordinal \\
\hline
\end{tabular}




\begin{tabular}{|c|c|c|c|c|c|}
\hline & & $\begin{array}{l}\text { psikologis, sehingga } \\
\text { mepengaruhi proses } \\
\text { berfikir,emosi,dan } \\
\text { kondisi seseorang } \\
\text { dalam menghadapi } \\
\text { pekerjaannya. }\end{array}$ & $\begin{array}{l}\text { 3. tuntutan } \\
\text { antar pribadi } \\
\text { 4. struktur } \\
\text { organisasi } \\
\text { 5. kepemimpina } \\
\text { n organisasi }\end{array}$ & & \\
\hline 3. & $\begin{array}{c}\text { Beban Kerja } \\
\left(\mathrm{X}_{2}\right)\end{array}$ & $\begin{array}{l}\text { Beban kerja adalah } \\
\text { sekumpulan atau } \\
\text { sejumlah kegiatan } \\
\text { kerja, yang harus } \\
\text { diselesaikan oleh } \\
\text { suatu unit organisasi } \\
\text { atau pemegang } \\
\text { jabatan dalam jangka } \\
\text { waktu tertentu. }\end{array}$ & $\begin{array}{l}\text { 1. target yang } \\
\text { harus dicapai } \\
\text { 2. Kondisi } \\
\text { pekerjaan } \\
\text { 3. Penggunaan } \\
\text { waktu } \\
\text { 4. standar } \\
\text { pekerjaan. }\end{array}$ & Kuisioner & Ordinal \\
\hline
\end{tabular}

\subsection{Hipotesis Penelitian}

Berdasarkan kerangka pemikiran di atas maka dapat dirumuskan Hipotesis sebagai berikut:

$\mathrm{H}_{1}$ : Ada pengaruh negatif dan signifikan antara stres kerja terhadap kinerja karyawan Dealer Honda Astra Motor Kota Bengkulu.

$\mathrm{H}_{2}$ : Ada pengaruh negatif dan signifikan antara beban kerja terhadap kinerja karyawan Dealer Honda Astra Motor Kota Bengkulu.

$\mathrm{H}_{3}$ : Ada pengaruh negatif dan signifikan secara simultan stres kerja dan $\mathrm{b}$ rja terhadap kinerja karyawan Dealer Honda Astra Motor Kota Bengkulu.

\section{BAB III}

\section{METODE PENELITIAN}

\subsection{Tempat dan Waktu Penelitian}

Penelitian ini dilaksanakan pada Dealer Honda Astra Motor Kota Bengkulu, Pada bulan Januari tahun 2020 sampai dengan selesai.

\subsection{Jenis Penelitian}

penelitian ini adalah penelitian Lapangan (field research) dengan menggunakan metode pendekatan Kuantitatif asosiatif yang bertujuan untuk mengetahui pengaruh stres 
kerja, dan beban kerja terhadap kinerja karyawan Dialer Honda Astra Motor Kota Bengkulu.

\subsection{Populasi dan Sampel}

Populasi adalah keseluruhan subjek penelitian yang dapat terdiri dari manusia, benda-benda, hewan, tumbuh-tumbuhan, gejala-gejala, nilai tes atau peristiwa-peristiwa sebagai sumber data yang memiliki karakteristik tertentu di dalam suatu penelitian (Margono,2009). Populasi dari penelitian ini adalah seluruh karyawan Dealer Honda Astra Motor Kota Bengkulu yang berjumlah 30 orang. Karena populasi pada penelitian ini berjumlah hanya 30 orang maka, penarikan sampel menggunakan tehnik sampling jenuh. Sampling jenuh adalah pengambilan seluruh populasi menjadi sampel (Sugiyono, 2012).

\subsection{Teknik Pengumpulan Data}

Dalam rangka pengumpulan data primer, penulis melakukan penelitian langsung, yaitu:

1. Observasi

Observasi merupakan suatu proses yang kompleks, suatu proses yang tersusun dari berbagai proses biologis dan psikhologis, Dua diantara yang terpenting adalah proses-proses pengamatan dan ingatan (Sugiyono, 2012). Pada penelitian ini observasi dilakukan pada Dealer Honda Astra Motor Kota Bengkulu.

2. Wawancara

Wawancara merupakan pertemuan dua orang untuk bertukar informasi dan ide melalui tanya jawab, sehingga dapat dikontruksikan makna dalam suatu topik tertentu (Sugiyono,2012). Wawancara dilakukan dengan pimpinan dan karyawan Dealer Honda Astra Motor Kota Bengkulu.

3. Kuisioner 
Kuisioner merupakan tehnik pengumpulan data yang dilakukan dengan cara memberi seperangkat pertanyaan atau pernyataan tertulis kepada responden untuk dijawabnya (Sugiyono, 2012). Kuisioner pada penelitian ini terdiri dari karakteristik responden, pernyataan pada Variabel stres kerja, dan beban kerja serta pernyataan pada variabel kinerja. Dimana setiap pertanyaan mempunyai 5 opsi sebagai berikut.

Tabel 3.1

Skala Ordinal

\begin{tabular}{|c|l|c|}
\hline No & \multicolumn{1}{|c|}{ Pernyataan } & Bobot \\
\hline 1 & Sangat Setuju (SS) & 5 \\
\hline 2 & Setuju (S) & 4 \\
\hline 3 & Netral (N) & 3 \\
\hline 4 & Tidak Setuju (TS) & 2 \\
\hline 5 & Sangat Tidak Stuju (STS) & 1 \\
\hline
\end{tabular}

Tabel 3.2

Kisi-Kisi Kuisioner

\begin{tabular}{|c|c|c|c|c|}
\hline No & variabel & Indikator & $\begin{array}{c}\text { No } \\
\text { Item }\end{array}$ & Jumlah \\
\hline 1 & Stres Kerja $\left(\mathrm{X}_{1}\right)$ & $\begin{array}{l}\text { 1. Tuntutan Tugas. } \\
\text { 2. Tuntutan peran } \\
\text { 3. Tuntutan antar pribadi } \\
\text { 4. Struktur organisasi } \\
\text { 5. Kepemimpinan organisasi }\end{array}$ & $\begin{array}{l}1-2 \\
3-4 \\
5-6 \\
7-8 \\
9-10\end{array}$ & $\begin{array}{l}2 \\
2 \\
2 \\
2 \\
2\end{array}$ \\
\hline Total & & 5 & 10 & 10 \\
\hline 2 & Beban Kerja $\left(\mathrm{X}_{2}\right)$ & $\begin{array}{l}\text { 1. Target yang harus dicapai } \\
\text { 2. Kondisi pekerjaan } \\
\text { 3. Penggunaan waktu } \\
\text { 4. Standar pekerjaan }\end{array}$ & $\begin{array}{l}1-2 \\
3-4 \\
5-6 \\
7-8 \\
\end{array}$ & $\begin{array}{l}2 \\
2 \\
2 \\
2\end{array}$ \\
\hline Total & & 4 & 8 & 8 \\
\hline 3 & $\begin{array}{c}\text { Kinerja karyawan } \\
\text { (Y) }\end{array}$ & $\begin{array}{l}\text { 1. Efektifitas dan efisiensi } \\
\text { 2. Otoritas dan tanggung } \\
\text { jawab } \\
\text { 3. Disiplin } \\
\text { 4. Inisiatif }\end{array}$ & $\begin{array}{l}1-2 \\
3-4 \\
5-6 \\
7-8 \\
\end{array}$ & $\begin{array}{l}2 \\
2 \\
2 \\
2\end{array}$ \\
\hline Total & & 4 & 8 & 8 \\
\hline
\end{tabular}




\subsection{Uji Instrumen Penelitian}

Pengujian instrumen penelitian yaitu menguji validitas dan reliabilitas variabel penelitian. Penggunaan metode pengumpulan data dengan kuesioner, maka kesungguhan responden mengisi kuesioner merupakan hal yang penting. Adapun Uji Instrumen yang dimaksud adalah menguji validitas dan reliabilitas yang dilakukan pada sampel uji, ditentukan dengan sampel Khusus sejumlah 20 orang responden diluar sampel penelitian. Instrumen yang valid dan reliabel merupakan syarat mutlak untuk mendapatkan hasil penelitian yang diharapkan. Data yang terkumpul di uji dengan bantuan program SPSS versi 16 for window dalam pengelolahan data.

\subsubsection{Uji Validitas Data}

Uji validitas digunakan untuk mengukur sah atau valid dalam suatu kuesioner. Uji validitas data ini dilakukan dengan melakukan korelasi bivariate atau product moment pearson antara masing-masing skor indikator dengan total skor variabel. Dasar pengambilan keputusan valid atau tidaknya pernyataan oleh Sugiyono (2013) :

Jika $r$ positif, serta $r \geq 0,30$ maka item pernyataan tersebut valid Jika $r$ negatif, serta $r \leq 0,30$ maka item pernyataan tersersebut tidak valid Namun untuk memudahkan uji valiiditas Data maka peneliti menggunakan program SPSS versi 24,0 for windows dalam pengelolahan data. Hasil uji validitas dapat dilihat pada lampiran no 3.

\subsubsection{Reliabilitas Data}

Uji Reliabilitas maksudnya untuk mengukur suatu angket yang merupakan indikator dari variabel. Reliabilitas data diukur dengan uji statistik alpha cronbach's (a). Suatu variabel dikatakan reliabilitas jika memberi nilai $\alpha>0,60$. Hasil uji reliabilitas dapat dilihat pada lampiran no 3 


\subsection{Teknik Analisis Deskriptif}

Bagian analisis ini akan membahas mengenai bentuk tanggapan responden terhadap kuisioner yang disebarkan kepada responden. Dari sebaran jawaban responden selanjutnya akan diperoleh satu kecendrungan jawaban responden terhadap jawaban masing-masing variabel akan akan didasarkan pada nilai rata-rata skor yang selanjutnya akan dikonfirmasikan pada tabel interval penelitian, adapun perhitungan rata-rata dari responden menggunakan rumus sebagai berikut:

$$
\begin{aligned}
& x=\frac{\sum x}{N} \\
& \text { Keterangan: } \\
& X=\text { angka rata-rata } \\
& N=\text { jumlah skor } \\
& \sum x=\text { nilai responden }
\end{aligned}
$$

Hasil rata-rata jawaban responden tersebut dikonfirmasikan pada interval penelitian menetapkan rentang interval penelitian tersebut. Dihitung berdasarkan rumus sebagai berikut:

$$
\begin{aligned}
& \mathrm{I}=\frac{\mathrm{R}}{\mathrm{K}} \\
& \text { Keterangan } \\
& \mathrm{I}=\text { interval } \\
& \mathrm{R}=\text { range (nilai tertinggi-nilai terendah) } \\
& \mathrm{K}=\text { jumlah kategori } \\
& =\frac{5-1}{5}=0,8
\end{aligned}
$$

Setelah besarnya interval diketahui, kemudian dibuat rentang skala sehingga dapat ditentukan kriteria penelitian persepsi responden terhadap variabel-variabel penelitian sebagai berikut: 
Tabel 3.3

Tanggapan Responden Terhadap Variabel

\begin{tabular}{|l|l|}
\hline Interval koefisien & Tingkat hubungan \\
\hline $4,20-5,00$ & Sangat setuju \\
$3,40-4,19$ & Setuju \\
$2,60-3,39$ & Netral \\
$1,80-2,59$ & Tidak setuju \\
$1,00-1,79$ & Sangat tidak setuju \\
\hline
\end{tabular}

Sumber : Coorper dan Emory, (2016)

\subsection{Uji Asumsi Klasik}

\subsubsection{Uji Normalitas}

Uji normalitas dimaksudkan untuk memperlihatkan data sampel berasal dari populasi yang berdistribusi normal. Metode yang digunakan untuk melakukan uji normalitas data dalam penelitian ini dengan menggunakan uji kolmogorovsmirnov, dengan kriteria kenormalan sebagai berikut:

1. Signifikansi uji $\alpha=0,05$.

2. Jika sig. $>\alpha$, maka sampel berasal dari populasi yang berdistribusi normal.

3. Jika sig. $<\alpha$, maka sampel bukan berasal dari populasi yang berdistribusi normal.

\subsubsection{Uji Multikolinearitas}

Uji Multikolinearitas bertujuan untuk mengetahui apakah ada korelasi antara variabel bebas yang satu dengan variabel bebas yang lain dalam model regresi yang digunakan. Semakin kecil korelasi diantara variabel bebasnya maka semakin baik model regresi yang akan diperoleh. Metode yang digunakan untuk mendeteksi adanya Multikolinearitas yaitu dengan menggunakan Tolerance dan Variance Inflantion factor (VIF) tidak lebih dari 10 dan nilai tolerance tidak 
kurang 0,1, maka model regresi dapat dikatakan bebas dari masalah Multikolinearitas.

\subsubsection{Uji Heteroskedastisitas}

Heteroskedastisitas adalah varian residual yang tidak sama pada semua pengamatan didalam model regresi. Regresi yang baik seharusnya tidak terjadi Heteroskedastisitas. Untuk mendeteksi ada tidaknya Heteroskedastisitas dengan melihat pola titik-titik pada scalterplots regresi, pengambilan keputusannya yaitu:

a. Jika pola tertentu, seperti titik-titik yang membentuk suatu pola tertentu yang teratur (bergelombang, melebar kemudian menyempit), maka terjadi Heteroskedastisitas.

b. Jika tidak ada pola yang jelas, seperti titik-titik menyebar diatas dan dibawah angka 0 pada sumbu Y, maka tidak terjadi Heteroskedastisitas.

\subsection{Teknik Analisis Data}

\subsubsection{Analisis Regresi Berganda}

Adapun model regresi berganda yang digunakan dalam penelitian ini adalah sebagai berikut:

$\mathrm{Y}=\beta \mathrm{o}+\beta 1 \mathrm{X} 1+\beta 2 \mathrm{X} 2+\mathrm{ei}$

Keterangan:

$\mathrm{Y} \quad=$ Kinerja Karyawan

$\mathrm{X} 1=$ Stres Kerja

$\mathrm{X} 2=$ Beban Kerja

Bo = Nilai Konstanta

$\beta 1=$ Koefisien regresi

ei $\quad=$ Variabel Pengganggu

3.8.2 Analisis Koefisien Determinasi 
Penguji koefisien determinasi digunakan untuk mengukur seberapa besar pengaruh dari seluruh variabel dependen yang ada dan besarnya pengaruh yang disebabkan oleh variabel lain tidak dapat dijelaskan. Hal ini ditunjukkan oleh besarnya koefisien determinan $\left(\mathrm{R}^{2}\right)$ yang besarnya antara 0 sampai 1 atau $0 \leq \mathrm{R}^{2} \leq 1$. Jika $\mathrm{R}^{2}$ mendekati 1, maka variabel independen berpengaruh terhadap variabel dependen dengan sempurna atau terdapat suatu kecocokan yang sempurna (variabel independen yang dipakai dapat menerangkan dengan baik variabel dependen). Namun jika koefisien determinasi adalah nol (0) berarti variabel independen tidak berpengaruh terhadap variabel dependen. (Sugiyono,2013). Koefisien determinasi dalam penelitian ini adalah mengukur pengaruh stres kerja (X1), dan beban kerja (X2), terhadap kinerja karyawan (Y). Rumus koefisien determinasi adalah sebagai berikut:

$$
\mathrm{Kd} \quad=\mathrm{R}^{2} \times 100 \%
$$

Keterangan:

$\mathrm{Kd}=$ Besar atau jumlah Koefisien Determinasi

$\mathrm{R}^{2}=$ Nilai koefisien Korelasi.

Sedangkan kriteria dalam melakukan analisis koefisien determinasi adalah sebagai berikut:

1. Jika Kd mendekati 0, berarti pengaruh variabel independen terhadap variabel dependen lemah,dan

2. Jika Kd mendekati 1 , berarti pengaruh variabel independen terhadap variabel dependen kuat.

Namun untuk memudahkan Uji koefisien determinasi maka peneliti menggunakan program SPSS versi 16 For Windows dalam pengolahan data.

\subsection{Pengujian Hipotesis}

Teknik uji T ini digunakan untuk menguji dan mengetahui apakah variabel bebas secara individual mempunyai pengaruh yang signifikan terhadap variabel terikat, 


\subsubsection{Uji t (parsial)}

Adapun cara pengujiannya sebagai berikut:

a. Tarif signifikansi $(\alpha)=0,05$

b. Jika sig. $<\alpha$, maka Ho ditolak dan Ha diterima

c. Jika sig. $>\alpha$, maka Ho diterima dan Ha ditolak

\subsubsection{Uji F (simultan)}

Uji F atau uji koefisien regresi secara serentak, yaitu untuk mengetahui pengaruh stres kerja, dan beban kerja terhadap kinerja karyawan Dealer Honda Astra Motor Kota Bengkulu apakah pengaruhnya signifikan atau tidak. Adapun cara pengujiannya didasarkan pada:

1) Tarif signifikansi $(\alpha)=0,05$

2) Jika sig. $>\alpha$, maka Ho ditolak dan Ha diterima

3) Jika sig. $<\alpha$, maka Ho diterima dan Ha ditolak.

\section{DAFTAR PUSTAKA}

Anjani, R. (2019). Tata Kelola Adminitrasi Keuangan, Dan Pembangunan Desa Tepi Laut Kabupaten Bengkulu Utara. Jurnal Pengabdian Masyarakat Bumi Raflesia, $2(2)$.

Arie, F. (2015), Pengaruh Beban Pekerjaan Terhadap Kinerja Karyawan: Efek Mediasi Burnout. Jurnal Akuntansi, Ekonomi dan Manajemen Bisnis. Vol 3. N 1.

Asmawi, M. (2017). The effect of compensation, empowerment, and job satisfaction on employee loyalty. International Journal of Scientific Research and Management, 5(12), 7590-7599.

Agung, (2008). Stres kerja (pengertian dan pengenalan) (online), http://agungpia.multiply. $\quad$ Com/journal/item/item/35/stres-pengertian-danpengenalan $=\mathrm{I} \& \mathrm{u}=\% 2$ fjournal diakses tanggal 08 november 2012

Bastian, (2006). Akuntansi Sektor Publik: Suatu Pengantar. Jakarta: Erlangga.

Bagus Setiawan Sutowoputro, (2016). pengaruh beban kerja dan stres kerja terhadap kinerja karyawan PT. Budi Sehat di Surakarta. Publising. 
Chandra, (2012), Pengaruh Beban Kerja dan Stres Kerja terhadap Kinerja Karyawan pada PT. Mega Auto Central Finance Cabang di Langsa. Universitas Samudra, Jurnal Manajemen dan keuangan, Vol 6. No.1, Mei 2017-ISSN 2252-844

Choiu,(2011)." Pengaruh stres kerja dan kepuasan kerja terhadap kinerja karyawan pada p.t. Lie fung surabaya". . Jurnal Administrasi Bisnis, Vol 6. No 2

Departemen Pendidikan Indonesia (2008). Kamus Besar Bahasa Indonesia. Jakarta: Balai Pustaka

Desy, Vita Helia, (2002). Tingkat stres kerja dan faktor berhubungan dengan stres kerja pada karyawan bagian marketing services PT Unilever Indonesia Tbk. Skripsi program serjana kesehatan masyarakat Univrsitas Indonesia.

Gibson, et al, (2009). Organisasi. Edisi kelima. Jakarta : Erlangga

Hasibuan, Malayu,(2003). Manajemen Sumber Daya Manusia, Edisi Revisi, Bumi Aksara, Jakarta.

Jeky K.R Rolos, (2018). Pengaruh beban kerja terhadap kinerja karyawan PT. Ansuransi Jiwasraya Cabang Manado Kota. Jurnal Administrasi Bisnis, Vol 6. No 4. ISSN:2338-9605.

Kahneman, Warr, (2002)." Pengaruh beban kerja terhadap kinerja karyawan. PT. Ansuransi Jiwaraya Cabang Manado Kota. Jurnal administrasi bisnis. Von 6 No 4. ISSN 2338-9605.

L.R. Sayle dan Straus, (2009) Pengaruh Beban Kerja dan Stres Kerja terhac Karyawan pada PT. Mega Auto Central Finance Cabang di Langsa. vinvusuus Samudra, Jurnal Manajemen dan keuangan, Vol 6. No.1, Mei 2017-ISSN 2252844

Lisnayetty dan Hasanbasri (2006). Pengaruh beban kerja terhadap kinerja karyawan PT. Ansuransi Jiwasraya Cabang Manado Kota. Jurnal Administrasi Bisnis, Vol 6. No 4. ISSN:2338-9605.

Mangkunegara, (2000). Manajemen Sumber Daya Manusia perusahaan. Cetakan ke-2, PT. Remaja Rosda Karya, Bandung.

Mangkunegara, (2009), manajemen sumber daya manusia. Bandung : PT. Remaja Rosda karyawa

Muhamad Zainur, (2010). Kepuasan Kerja, Malang: Averroes Press.

Mangkunegara, (2005). Manajemen Sumber daya Manusia Perusahaan. Bandung : PT Remaja Rosdakarya.

Malayu. (2009). Manajemen Sumber Daya Manusia. Bumi Aksara, Jakarta

Munafiah Siti. 2011. Pengaruh Kompensasi dan Supervisi terhadap Kinerja Karyawan (Studi Kasus pada PT. Industri Sandang Nusantara Unit Patal Secang). Skripsi. FE Universitas Negeri Yogyakarta 
Margono. S, (2009). Metodologi penelitian pendidikan komponen MKDK. Jakarta: PT Rineka Cipta.

Novitasari, (2003). "Pengaruh Stress Kerja Terhadap Motivasi Kerja Dan Kinerja Karyawan PT. H.M. Sampoerna Tbk. Studi Pengembangan SDA Program Pasca Sarjana Universitas Airlangga

Onsardi, O. (2018). Loyalitas Karyawan pada Universitas Swasta di Kota Bengkulu. COSTING: Journal of Economic, Bussines and Accounting, 2(1), 1-13.

Onsardi, O. (2019). Effect Of Empowerment On Employees Performance (No. v7g9t). Center for Open Science.

Permendagri, PerMen DamNeg No. 12 tahun 2008 tentang Pedoman Analisa Beban Kerja di Lingkungan Departemen Dalam Negeri dan Pemerintah Daerah Jakarta (2008).

Prawirosentono. (2008). Manajemen Sumber Daya ManusiaKebijakan Kinerja Karyawan”. Yogyakarta:BPFE.

Putra, A Syukriansyah. (2012). "Analisis pengaruh beban kerja terhadap kinerja karyawan Devisi marketing dan Kredit. PT WOM Finance Cabang Depok". Jurnal studi manajemen indonesia. Hal :22

Riny Chandra, Dody Adriyansyah. 2017, Pengaruh Beban Kerja dan Stres Ker: tahodno Kinerja Karyawan pada PT. Mega Auto Central Finance Cabang Universitas Samudra, Jurnal Manajemen dan keuangan, Vol 6. No.1, ISSN 2252-844

Robbins, S. P (2006). Perilaku organisasi. Alih Bahasa: Benyamin Molan. Edisi Kesepuluh Penerbit PT. Indeks, kelompok Gremedia. Jakarta.

Robbins, Stephen P. (2003). Perilaku Organisasi. Index Jakarta.

Robbins, Stephen P. (2007). Perilaku Organisasi. Indonesia : PT Macanan Jaya

Sugiyono, Metode Penelitian Kuantitatif Kualitatif dan R\&D, (Bandung:Alfabeta,2011).

Sugiyono,(2013). Metode penelitian kuantitatif, kualitatif dan $R \& D$. Bandung: Alfabeta. CV

Sedarmayanti, (2009). Sumber Daya Manusia dan Produktivitas Kerja. Bandung: CV Mandar Maju

Suwanto \& Priansa, D. (2011). Manajemen SDM dalam Organisasi Publik dan Bisnis. Bandung : Alfabeta.

Suyadi Prawirosentono. (2008). Manajemen Sumber Daya ManusiaKebijakan Kinerja Karyawan". Yogyakarta:BPFE.

Siagian. (2012). Manajemen Sumber Daya Manusia, Bumi Aksara. Jakart 
Sedarmayanti, (2011). Manajemen Sumberdaya Manusia, reformasi birokrasi dan manajemen pegawai negri sipil. Bandung : PT. Refika Aditama.

Sunyoto, Danang. (2013). Sumber Daya Manusia. Yogyakarta: Caps

Siagian, Sondang P. (2012). Kiat meningkatkan Produktivitas kerja. Jakarta: Rineka Cipta.

Salye, Jaza A Chusna, (2010). Pengaruh Stres Kerja terhadap Kinerja Karyawan pada Kantor Pengelola It Center Manado. Jurnal Administrasi Bisnis, Vol 6. No 2 tahun 2018

Sunarso. (2010). Pengaruh Kepemimpinan, Kedisiplinan, Beban Kerja dan Motivasi Kerja terhadap Kinerja Guru Sekolah. Jurnal Managemen Sumber Daya Manusia. Vol 4. No 1.

Suprihanto, J. (2003). Perilaku Organisasional. Yogyakarta: Sekolah Tinggi Ilmu Ekonomi YKPN.

Shahu, Rashmi dan S.V. Gole, (2008), Effect of Job Stress and Job Sat Performance: An Empirical Study, AIMS International Journal of 1 2(3). pp 237-246

Uno, (2012). Teori kinerja dan pengukurannya, Jakarta: Bumi Aksara.

Undang- undang kesehatan RI No 36 tahun 2009 Tentang kesehatan. http:// sireka.Pom.go.id.

William A. Aresos, dkk, (2018). "pengaruh stres kerja terhadap kinerja karyawan pada kantor pengelola IT Center Manado". Jurnal Administrasi Bisnis, Vol.6. No. 2. Tahun 2018.

Wirawan. (2009). Evaluasi Kinerja Sumber Daya Manusia Teori Aplikasi dan Penelitian. Jakarta. Penerbit: Salemba Empat.

Walker, J. (2002). Teens in distressseries Adolescent stress and depresion. Minnesota University.

Yusuf, (2004). Pengaruh stres kerja dan beban kerja terhadap kinerja SKPD Kabupaten Siantang Kalimantan Barat. Jurnal Maksipreneur, Vol 4. No.2, hal 15-27. 